\title{
Maxillofacial injuries among Brazilian children and adolescents victims of traffic accidents
}

\author{
Lesões maxilofaciais em crianças e adolescentes brasileiros vítimas de acidentes de trânsito
}

Laís Gonzaga de FARIAS'

Rebeca Valeska Soares PEREIRA ${ }^{1}$

Lorenna Mendes Temóteo BRANDT ${ }^{1}$

Thaliny Batista Sarmento de OLIVEIRA²

Alidianne Fábia Cabral XAVIER ${ }^{1}$

Alessandro Leite CAVALCANTI'

\section{ABSTRACT}

\section{Objective}

To analyze the prevalence of morbidity due to traffic accidents in children and adolescents and its relationship with maxillofacial injuries in the city of Campina Grande, Paraiba, Brazil.

\begin{abstract}
Methods
This cross-sectional study analyzed 533 forensic reports of individuals aged 0-19 years, victims of external causes in Campina Grande, Brazil, in 2013. Data were collected through a form containing variables sex, age, day of week, time, type of traffic accident, injured body region, presence of fractures, maxillofacial and oral cavity injuries. The Statistical Package for Social Sciences software (SPSS) was used for data analysis. Prevalence ratios and confidence intervals at 95\% were estimated with the chi-square test.
\end{abstract}

\section{Results}

There was predominance of males (75.0\%) aged $15-19$ years (65.0\%), with association between sex and occurrence of traffic accidents (p $<0.001$ ). The afternoon shift recorded $36.7 \%$ of cases of accidents involving motorcyclists (55.0\%). In $25.0 \%$ of cases, there were injuries on the head and $26.7 \%$ on the face. Head and face injuries were observed in $10.0 \%$ of patients, while maxillofacial and oral cavity injuries were present in $21.7 \%$ and $6.7 \%$, respectively. There was an association between occurrence of accident and face injuries $(p=0.009)$.

\section{Conclusion}

Traffic accidents affect mostly young male individuals, causing multiple injuries in different body areas, including maxillofacial and oral cavity injuries.

Indexing terms: Accidents, traffic. Maxillofacial injuries. Morbidity.

\section{RESUMO}

\section{Objetivo}

Analisar a prevalência de morbidade por acidentes de trânsito em crianças e adolescentes e sua relação com lesões maxilofaciais na cidade de Campina Grande, Paraíba, Brasil.

\section{Método}

Estudo transversal, que analisou 533 laudos de exames de corpo de delito de indivíduos de 0 a 19 anos vitimados por causas externas em Campina Grande, Brasil, no ano de 2013. Os dados foram coletados por meio de um formulário, contendo as variáveis sexo, faixa etária, dia da semana, horário, tipo de acidente de trânsito, região do corpo acometida, presença de fratura, lesão maxilofacial e lesão na cavidade bucal. Utilizou-se o software Statistical Package for the Social Sciences (SPSS) para análise dos dados. Foram estimadas as razões de prevalência e intervalos de confiança a 95\%, com emprego do teste do Qui-quadrado.

\section{Resultados}

Houve predominância do sexo masculino (75,0\%), e da faixa etária de 15 a 19 anos (65,0\%), existindo associação entre sexo e ocorrência de acidente de transporte $(p<0,001)$. O turno da tarde registrou $36,7 \%$ dos casos e os acidentes envolvendo motociclistas $55,0 \%$. Em $25,0 \%$ dos casos houve injúrias na cabeça e em $26,7 \%$ na face. Fratura na cabeça e face foi verificada em 10,0\% da amostra, enquanto lesões maxilofaciais e na cavidade bucal estiveram presentes em $21,7 \%$ e 6,7\%, respectivamente. Verificou-se associação entre ocorrência do acidente e acometimento da região da face $(p=0,009)$.

\section{Conclusão}

Os acidentes de trânsito acometem indivíduos jovens, do sexo masculino, acarretando múltiplas injúrias em distintas regiões do corpo, com lesões na região maxilofacial e cavidade bucal.

Termos de indexação: Acidentes de trânsito. Traumatismos maxilofaciais. Morbidade.

\footnotetext{
${ }^{1}$ Universidade Estadual da Paraíba, Centro de Ciências Biológicas e da Saúde, Departamento de Odontologia. Av. das Baraúnas, s/n., Bodocongó, 58109-753, Campina Grande, PB, Brasil. Correspondence to: AL CAVALCANTI. E-mail: <dralessandro@ibest.com.br>.

${ }^{2}$ Universidade Estadual da Paraíba, Programa de Pós-Graduação em Saúde Pública. João Pessoa, PB, Brasil.
} 


\section{INTRODUCTION}

In recent years, a steady increase in morbidity due to external causes has been observed ${ }^{1}$. Among them, traffic accidents stand out, since it is estimated that from 20 to 50 million people survive with different traumas ${ }^{2}$.

Traffic accidents arouse great concern in the health sector due to their impact on morbidity and mortality, and, above all, for reaching young people with high number of potential years of life lost and the consequent reduction in life expectancy, as well as spending on emergency services and consequences reflected in family and social context ${ }^{3}$.

An increasing involvement of children and adolescents has been observed, especially as pedestrians and vehicle occupants up to 14 years of age, who become drivers from the age of $15^{4}$. In Brazil, over a hundred thousand hospitalizations for injuries resulting from traffic accidents are recorded each year, in addition to victims who are attended in emergency services and released shortly after ${ }^{5}$.

The maxillofacial region, as well as the facial bones that compose it, has greater vulnerability to trauma in two circumstances: car accidents and violence ${ }^{6}$. Specifically, in the first case, attention should be given to the age group of 0-19 years, since fractures in the maxillofacial region are constant occurrences because automobile accidents are prevalent in this population?

Considering the above, this study aims to analyze epidemiological data on morbidity due to traffic accidents among children and adolescents and their relationship with maxillofacial injuries in the city of Campina Grande (PB), in 2013.

\section{METHODS}

Cross-sectional study carried out based on the analysis of 533 forensic medical reports of children and adolescents, in 2013 in the Center for Forensic Medicine and Dentistry (NUMOL) of Campina Grande, Brazil.

Data were collected by two researchers, who analyzed the following variables: gender, age, day of week, time of occurrence, type of traffic accident, body region affected, presence of fracture, maxillofacial injury and oral cavity lesion.

Descriptive statistics (absolute and percentage distributions, mean, median and standard deviation) was used. The bivariate analysis used the chi-square test. Prevalence ratios and their respective confidence intervals at $95 \%$ were estimated using the SPSS software (Statistical Package for the Social Sciences), version 18.0.

According to Resolution 466/12 of the National Health Council, the research was approved by the Research Ethics Committee of the State University of Paraiba (0443.0133.000-11).

\section{RESULTS}

Of the 533 medical reports analyzed, 60 (11.3\%) were due to traffic accidents, with prevalence of male victims (75.0\%). The bivariate analysis revealed an association between gender and the occurrence of traffic accidents ( $p<0.001 ; P R=3.50$ [1.90 to 6.46]).

The age of the victims ranged from 0 to 19 years, with average of 14.35 years $( \pm 5.3)$ and median of 17 years. The age group 15-19 years was the most affected (65.0\%) (Table 1).

Table 1. Distribution of traffic accident victims by gender and age group. Campina Grande (PB), 2013.

\begin{tabular}{|c|c|c|c|c|c|c|c|c|c|c|}
\hline \multirow{3}{*}{ Gender } & \multicolumn{8}{|c|}{ Age (in years) } & \multirow{2}{*}{\multicolumn{2}{|c|}{ Total }} \\
\hline & \multicolumn{2}{|c|}{0 to 4} & \multicolumn{2}{|c|}{5 to 9} & \multicolumn{2}{|c|}{10 to 14} & \multicolumn{2}{|c|}{15 to 19} & & \\
\hline & $n$ & $\%$ & $n$ & $\%$ & $n$ & $\%$ & $\mathrm{n}$ & $\%$ & $\mathrm{n}$ & $\%$ \\
\hline Female & 3 & 5.0 & 2 & 3.3 & 2 & 3.3 & 8 & 13.3 & 15 & 100.0 \\
\hline Total & 5 & 8.3 & 11 & 18.4 & 5 & 8.3 & 39 & 65.0 & 60 & 100.0 \\
\hline
\end{tabular}

Figure 1 shows the distribution of occurrences according to the day of week, indicating that most of the accidents occurred on Thursdays (21.7\%) and Tuesdays (18.3\%). On the other hand, the day showing the lowest number of events was Saturday $(8.3 \%)$. 


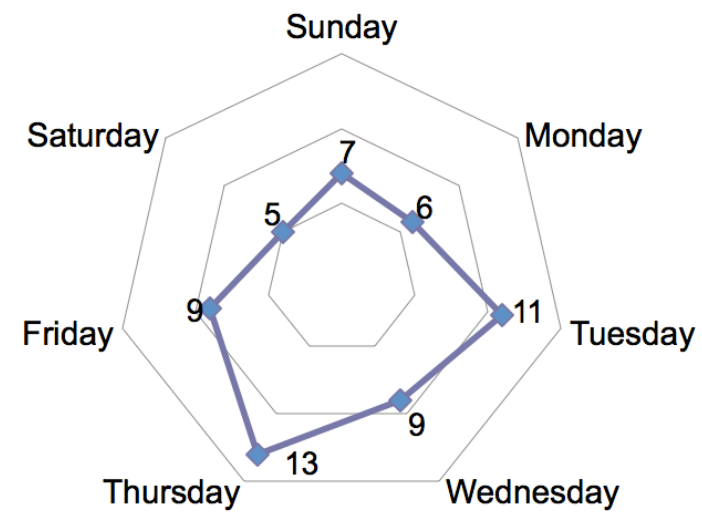

Figure 1. Percentage distribution of morbidity from traffic accidents according to the day of week. Campina Grande (PB), 2013.

As for the time of accident occurrence, in $36.7 \%$ of cases, the afternoon period prevailed followed by night
(31.7\%) and morning periods (11.7\%). The morning period showed the lowest reported cases (10.0\%). In 10\% of reports, there was no time of accident occurrence.

The analysis of the type of automotive accident showed prevalence of accidents involving motorcycles with a total of $55.0 \%$ ( $n=33$ ) of cases, followed by accidents involving pedestrians $(n=16)$ and vehicle occupants $(n=$ 11), with $26.7 \%$ and $18.3 \%$ respectively.

For the body regions affected by some kind of injury resulting from automotive accidents, lower and upper limbs concentrated $50.0 \%$ and $40.0 \%$ of cases, respectively. It was found that $25.0 \%$ of medical reports mentioned the occurrence of injuries on the head and $26.7 \%$ on the face region (Table 2 ). It was found that there is a significant association between occurrence of traffic accident and involvement of the face $(p=0.009)$ and lower limbs $(p=0.001)$.

Table 2. Distribution of injuries according to the body region affected. Campina Grande (PB), 2013.

\begin{tabular}{|c|c|c|c|c|c|c|c|c|}
\hline \multirow{3}{*}{ Body region } & \multicolumn{4}{|c|}{ Traffic accident } & \multirow{2}{*}{\multicolumn{2}{|c|}{ Total }} & \multirow{3}{*}{ p-value } & \multirow{3}{*}{ PR } \\
\hline & \multicolumn{2}{|c|}{ Yes } & \multicolumn{2}{|c|}{ No } & & & & \\
\hline & $n$ & $\%$ & $\mathrm{n}$ & $\%$ & $\mathrm{n}$ & $\%$ & & \\
\hline Head & & & & & & & & 1.88 \\
\hline No & 45 & 75.0 & 401 & 85.0 & 446 & 83.8 & & \\
\hline Face & & & & & & & 0.009 & 0.45 \\
\hline Yes & 16 & 26.7 & 210 & 44.5 & 226 & 42.5 & & $(0.24-0.82)$ \\
\hline Yes & 24 & 40.0 & 208 & 44.1 & 232 & 43.6 & & $(0.49-1.46)$ \\
\hline No & 36 & 60.0 & 264 & 55.9 & 300 & 56.4 & & \\
\hline Lower limbs & & & & & & & 0.001 & 3.14 \\
\hline Yes & 30 & 50.0 & 114 & 24.2 & 144 & 27.1 & & $(1.81-5.43)$ \\
\hline No & 30 & 50.0 & 358 & 75.8 & 388 & 72.9 & & \\
\hline
\end{tabular}

The occurrence of general fracture was Regarding injuries, maxillofacial injuries were present demonstrated in $28.3 \%$ of the study population, in $21.7 \%$ of cases and oral cavity injuries in $6.7 \%$ while head and face fractures occurred in only 10.0\%. (Table 3).

Table 3. Distribution of victims according to the presence of injury according to the type of lesion. Campina Grande (PB), 2013

\begin{tabular}{lcc}
\hline Variable & $\mathrm{n}$ & Frequency \\
\hline General fracture & 17 & 28.3 \\
Yes & 13 & 71.7 \\
No & 43 & \\
Head/Face fracture & 6 & 10.0 \\
Yes & 54 & 90.0 \\
No & & \\
Maxillofacial injury & 13 & 21.7 \\
Yes & 47 & 78.3 \\
No & & \\
Oral cavity injury & & \\
Yes & 4 & 6.7 \\
No & 56 & 93.3 \\
\hline
\end{tabular}




\section{DISCUSSION}

Traffic accidents are a serious public health problem, especially in Brazil, since it has high rates when compared to other countries. This reality is reason for concern, especially when children and adolescents are among victims ${ }^{8}$.

Traffic accidents involve substantial spending on health care provided to victims, affect economically active individuals, resulting in loss of potential years of life and in increased expenditure arising from rehabilitation of sequelae ${ }^{9}$.

In the present investigation, greater involvement of men was observed, a result similar to that seen in other studies $^{10,11}$. Probably, this male victimization occurs as a result of their greater exposure to traffic and to social and cultural behaviors of this population segment ${ }^{12}$.

With regard to age, the results found were supported by national $\left.\right|^{13}$ and international ${ }^{14}$ surveys, which indicated the age group of 15-19 years as the age group with a large number of individuals victimized by the occurrence of traffic accidents. Possible factors associated to this problem are traffic inexperience and easy acquisition of motor vehicles, especially those on two wheels.

As for the day of week, Thursday showed the largest number of cases, unlike the results from studies conducted in the state of Paraná ${ }^{15,16}$, in which events were predominantly recorded on the weekends. Hypothetically, it is believed that the local reality can act decisively in the habits of young people in order to intensify the occurrence of accidents at different times.

Motorcyclists have occupied the first place among victims of traffic accidents and are at risk of death seven times higher compared to car drivers ${ }^{17}$. This assertion is confirmed by the results presented, which showed that accidents involving motorcyclists are more numerous when compared to other types of traffic accidents. Morbidity due to motorcycle accidents is quite relevant, with higher predominance in relation to vehicle occupants ${ }^{18}$.

The increased vulnerability of motorcyclists is evident, since in the collision, the occurrence of unequal shock with larger vehicles is quite frequent. It is noteworthy that the motorcyclist does not have the structure of a vehicle as protection, thus absorbing all the energy from the impact ${ }^{19}$. It is assumed that in the state of Paraíba, there is an increasing growth in the number of motorcycles and paradoxically, there is lack of investment in traffic education.
In this study, traffic accidents involving pedestrians appear as the second most recurrent type. Literature ${ }^{20}$ points children as largely vulnerable due to their lower perception of danger, their mental and physical immaturity to follow traffic rules, the spirit of competition and characteristic speed, in addition to the lack of respect to the condition of pedestrian by car drivers.

The body regions most affected in traffic accidents are upper and lower limbs, followed by the head region ${ }^{21,22}$. It is suggested that the higher incidence of upper and lower limbs at the age group of 0-19 years verified this study is due to the greater exposure and lack of protection when considering traffic accidents as morbidity etiology. These results are consistent with other findings previously described ${ }^{23}$.

Maxillofacial injuries were observed in a significant number of cases, which is consistent with the study by Pereira et al. ${ }^{24}$, in which it was found that the face is commonly affected in all types of traffic accidents. In the study by Vieira et al. ${ }^{25}$, the results showed that traffic accidents caused some kind of maxillofacial and / or oral cavity injury, finding corroborated by the results of this study and the results obtained by Cavalcanti et al. ${ }^{26}$.

Understanding the circumstances in which traffic accidents occur, the associated factors and their magnitude and consequences becomes essential not only to highlight this tragic reality, but mainly to find solutions ${ }^{27}$. These solutions must include strategies to prevent accidents to avoid the impact caused on individuals and society and because these events are considered preventable ${ }^{28}$.

\section{CONCLUSIONS}

It was concluded that young males were the main victims of traffic accidents, especially involving motorcycles and injuries in the lower limbs and in the maxillofacial region, with a small number of cases of injury in the cavity oral.

There is need to strengthen health services and other relevant sectors in order to act on factors that determine the occurrence of these events and minimize their occurrence.

\section{Acknowledgments}

We would like to thank the support received from NUMOL in the person of director Márcio Leandro da Silva and the entire team of health professionals. 


\section{Collaborators}

LG Farias, RVS PEREIRA, LMT BRANDT and TBS OLIVEIRA participated in the study design, data collection and writing of the manuscript. AFC XAVIER and AL CAVALCANTI participated in the conception and study design, coordination of data collection, statistical analysis and writing of the manuscript.

\section{REFERENCES}

1. Cocco M, Lopes MJM. Morbidade por causas externas em adolescentes de uma região do município de Porto Alegre. Rev Eletr Enferm. 2010;12(1):89-97.

2. Organização Mundial da Saúde. Informe sobre la situación mundial de la seguridad vial: es hora de pasar a la acción. Suíça: OMS; 2010.

3. Magalhães AF, Lopes CM, Koifman RJ, Muniz PT. Prevalência de acidentes de trânsito autorreferidos em Rio Branco, Acre. Rev Saúde Pública. 2011;45(4):738-44. doi: 10.1590/S003489102011005000031

4. Gawryszewski VP, Coelho HMM, Scarpelini S, Zan R, Jorge MHPM, Rodrigues EMS. Perfil dos atendimentos a acidentes de transporte terrestre por serviços de emergência em São Paulo, 2005. Rev Saúde Pública. 2009:43(2):275-82. doi: 10.1590/ S0034-89102009000200008

5. Jorge MHPM, Koizumi MS. Sequelas visíveis dos acidentes de trânsito: primeiros dados brasileiros. Abramet. 2011;29(1):3645.

6. Karyouti SM. Maxillofacial injuries at Jordan University Hospital. Int J Oral Maxillofac Surg. 1987;16(1):262-65. doi: 10.1016/S0901-5027(87)80145-5

7. Conto F, Santos RS, Rhoden R, Nicolini IC. Levantamento epidemiológico das fraturas de face no hospital São Vicente de Paulo, Passo Fundo, RS. Rev Fac Odontol. 2003;8(2):80-4.

8. Freibeger MF, Silva DG, Rodrigues JDN, Lima E, Silva PM. Violência no trânsito com crianças e adolescentes: um relato de experiência. Rev Cien Fac Edu Mei Amb. 2011;35(2):80-2.

9. Caixeta CR, Minamisava R, Oliveira LMAC, Brasil VV. Morbidade por acidentes de transporte entre jovens de Goiânia, Goiás. Ciênc Saúde Coletiva. 2010;15(4):2075-84. doi: 10.1590/ S1413-81232010000400021

10. Soares BAC, Scantena JHG, Galvão ND. Acidentes e violências na grande Cuiabá: o que retrata a demanda dos serviços de emergência. Epidemiol Serv Saúde. 2009;18(3):265-76. doi: 10.5123/S1679-49742009000300009

11. Gorios C, Souza RM, Gerolla V, Maso B, Rodrigues CL, Armond JE. Acidentes de transporte de crianças e adolescentes em serviço de emergência de hospital de ensino, Zona Sul da cidade de São Paulo. Rev Bras Ortop. 2013;49(4):391-5. doi: 10.1016/j. rbo.2013.10.008

12. Andrade SM, Jorge MHPM. Características das vítimas por acidentes de transporte terrestre em município da região Sul do Brasil. Rev Saúde Pública. 2000; 34(2):149-56. doi: 10.1590/ S0034-89102000000200008

13. Gaspar VLV, Souza ECO, Carmo JH, Pereira WT. Características de crianças e adolescentes hospitalizados em decorrência de causas externas. Rev Med. 2012;22(3):287-95.

14. Mulye TP, Park MJ, Nelson CD, Adams SH, Irwin CE, Brindis CD. Trends in Adolescent and Young Adult Health in the United States. J Adolesc Health. 2009;45(1):8-24. doi: 10.1016/j. jadohealth.2009.03.013

15. Golias ARC, Caetano R. Acidentes entre motocicletas: análise dos casos ocorridos no estado do Paraná entre julho de 2010 e junho de 2011. Ciênc Saúde Coletiva. 2013;18(5):1235-46. doi: $10.1590 / \mathrm{S} 1413-81232013000500008$

16. Silva DW, Soares DA, Andrade SM. Atuação profissional de motoboys e fatores associados à ocorrência de acidentes de trânsito em Londrina-PR. Epidemiol Serv Saúde. 2008;17(2):135-7.

17. Bastos YGL, Andrade SM, Soares DA. Características dos acidentes de trânsito e das vítimas atendidas em serviço pré-hospitalar em cidade do Sul do Brasil, 1997/2000. Cad Saúde Pública. 2005:21(3):815-22. doi: 10.1590/S0102$311 \times 2005000300015$

18. Pereira WAP, Lima MADS. Atendimento pré-hospitalar: caracterização das ocorrências de acidente de trânsito. Acta Paul Enferm. 2006;19(3):279-83. doi: 10.1590/S010321002006000300004

19. Oliveira NLB, Sousa RMC. Motociclistas frente as demais vítimas de acidentes de transito no município de Maringá. Acta Scientiarium. 2004;26(2):303-10. doi: 10.4025/actascihealthsci. v26i2.1581

20. Feitas JPP, Ribeiro LA, Jorge MT. Vítimas de acidentes de trânsito na faixa etária pediátrica atendidas em um hospital universitário: aspectos epidemiológicos e clínicos. Cad Saúde Pública. 2007;23(12):3055-60. doi: 10.1590/S0102$311 \times 2007001200028$

21. Brasileiro BF, Vieira JM, Silveira CES. Avaliação de traumatismos faciais por acidentes motociclísticos em Aracaju/SE. Rev Cir Traumatol Buco-maxilo-fac. 2010;10(2):97-104

22. Calil AM, Sallum EA, Domingues CA, Nogueira LS. Mapeamento das lesões em vítimas de acidentes de trânsito: revisão sistemática da literatura. Rev Latino-am Enfermagem. 2009;17(1):120-5. doi: 10.1590/S0104-11692009000100019

23. Malta DC, Macarenhas MDM, Bernal RTI, Andrade SSCA, Neves ACM, Melo EM, et al. Causas externas em adolescentes: atendimentos em serviços sentinelas de urgência e emergência nas Capitais Brasileiras - 2009. Ciênc Saúde Coletiva. 2012;17(9):2291-2304. doi: 10.1590/S141381232012000900011

24. Pereira MD, Kreniski T, Santos RA, Ferreira LM. Trauma craniofacial: perfil epidemiológico de 1223 fraturas atendidas 
entre 1999 e 2005 no Hospital São Paulo - UNIFESP-EPM. Rev Soc Bras Cir Craniomaxilofac. 2008;11(2):47-50.

25. Vieira CL, Araújo DCC, Ribeiro MLS, Laureano Filho JR. Lesão de tecido mole em pacientes vítimas de trauma buco-maxilo-facial. Rev Cir Traumatol Buco-maxilo-fac. 2013;13(1):89-96.

26. Cavalcanti AL, Monteiro BVB, Oliveira TBS, Ribeiro RA, Monteiro BSB. Mortalidade por acidentes de trânsito e ocorrência de fraturas maxilofaciais. Rev Bras Odontol. 2011;68(2):220-4.

27. Jorge MHPM, Martins CBG. A criança, o adolescente e o trânsito: algumas reflexões importantes. Rev Associa Med Bras. 2013;59(3):199-208. doi: 10.1016/j.ramb.2012.11.007
28. Brasil. Ministério da Saúde. Política Nacional de Redução da Morbimortalidade por Acidentes e Violências. $2^{a}$ ed. Brasília: Ministério da Saúde; 2005 [citado 2014 Out 10]. Disponível em: $<$ http://bvsms.saude.gov.br/bvs/publicacoes/politica_reducao_ morbimortalidade_acidentes_2ed>

Received on: 17/9/2014

Final version resubmitted on: 3/10/2015

Approved on: 5/1/2015 